\title{
O homem do castelo
}

\section{Carolina Marinho ${ }^{1}$}

Eis a história... . Era um homem de nobre estirpe que habitava um belo castelo erguido no topo de uma montanha que tocava o céu. Foi num tempo antigo e longínquo, em um lugar impreciso, já varrido do mapa. Lá em baixo perlongava uma aldeia habitada por tranqüilos homens que viviam no feliz. Muitamente trabalhavam em suas pequenas tarefas. Inventavam a vida que se passava em alegres dias...

O Homem do castelo pouco descia. Suas caminhadas eram por pensamentos que encontravam as nuvens. A luz do dia se apagava e vinha a lua, sempre cheia, clarear o topo do mundo.Daquele mundo ali cravado nas rochosas montanhas. Na aldeia, a lua minguava, crescia, encheiava e desaparecia cumprindo o seu ciclo rotineiro e instável.

Nos frios dias de inverno a aldeia recolhia-se do branco. No alto do castelo, o Homem avistava as luzes do fogo alumiando o interior das casas. Demorados dias se faziam... E nas noites incandescentes, as tímidas luzes das tochas agregavam os homens. Os aldeões se reuniam e contavam histórias. Muitas histórias... O senhor do castelo era envolto por lendas. Estranha vida entranhada por mistérios, percorria os labirintos do castelo sem princesa.

Havia também o cão, o gato e o camundongo, inseparáveis amigos. O Homem tinha uma obsessão e uma fraqueza imensa que Ihe consumia os sentidos. A brevidade da vida não Ihe conformava. Nuvens esgarçadas lhe escapavam a compreensão. Fugia-lhe a forma sugerida. Fugia-Ihe o pensamento rebelde.E ele trabalhava noite e dia buscando a eternidade...

Uma vez adoeceu. Teve calafrios pelo corpo, dores, febre alta e delírios. No frêmito, o mundo rodava repassando a vida e criando um por vir. Barulhos do vento e dos bichos ao longe se faziam... Aves de rapina roubavam-Ihe os sonhos que voavam na imensidão do céu. Perdiam-se das vistas, perdiam-se dos sentidos. E o Homem voou em busca dos seus sonhos. Percorreu aquele brilhante céu e penetrou no buraco negro, corredor de estrelas que cintilavam no espaço. Mundo de Alice! Pensou rápido e não pode se deter. Súbito acordou e crendo que chegava a sua hora foi tomado de coragem. Sorveu o elixir. Era tudo e era nada. Nadou no mar de estrelas e o céu encontrou a terra. Tomou o esverdeado líquido das finas ervas que cultivava. Compartilhou a experiência com seus companheiros: o cão, o gato e o camundongo.Três. Comungavam. Dormiram depois longos dias, longos meses, longos anos, talvez... O castelo silenciou-se. As ervas se agigantaram espantosamente subindo ao céu.O tempo lá em cima parou. E os aldeões, perplexos com o assustador silêncio, perceberam o estranho. Impotentes, nada fizeram. Apenas tiveram medo.

Foi ai que se deu o acontecido. O Homem acordou sem princesa, sem beijo, sem amor, sem promessas. Depois acordou o cão, e o gato e o camundongo. O castelo criou vida e acordou também. As paredes ganharam voz, como voz também ganhou o cão e o gato. 0 camundongo gesticulava aflito e mudo. A lucidez doía-lhe o pequeno crânio. O Homem percebeu que tudo havia em muito mudado. A lua sumiu do céu e as ervas murcharam-se vencidas. Reinava uma invisível força movendo a vida.

Da aldeia, os homens não viam mais o castelo. Densas nuvens cobriram para sempre o topo da montanha. Depois veio a guerra e a aldeia virou pó. O Homem então quis partir.O tempo se adiantava aceleradamente. O Homem reconheceu a chegada da eternidade. Ele, o cão, o gato e o camundongo eram para sempre. Reuniram-se para a viagem. $O$ camundongo quis ficar. Criava famílias e famílias, que iam e que vinham, outras e outras.Gostava do movimento da procriação.

1 Celisa Carolina Alvares Marinho. Doutora em Estudos Comparados de Literaturas de Língua Portuguesa, FFLCH-USP. 
Os três desceram do topo e as ervas, como que por encantamento, cobriram novamente o castelo serrando-o em concha. Espessos galhos espinhosos garantiam o isolamento da enorme propriedade. O Homem sorriu feliz ao compreender o poder e caminharam para o mar. Ele, o gato e o cão...

\section{A Viagem}

Naquele dia longamente caminharam. Percorreram vastas planícies, atravessaram largos rios, avançaram por imensos prados até alcançarem o mar. Viajaram sobre as águas por longos sois... E aí atravessaram a terra e os oceanos do tempo. Chegaram então nos trópicos na região das Américas.

A fumaça de pensamento dos dois animais foi varrida pelas palavras. O verbo causava-lhes perturbação. Compridos pensamentos confundiam a outrora primitiva percepção do mundo. Junto a isso o espaço se ampliava. Novas paisagens abriam os horizontes dos viajantes.

O sábio e discreto gato tinha o dom de ver além, ver por dentro e pelo avesso, contemplado agora por largo raciocínio. Atento observador, nada the escapava. A liberdade dos abertos espaços tocava seus instintos mas a luminosidade ofuscava-lhe a vista. A ambigüidade se instaurava. Vasto mundo penetrado de luz. Ele se amplificava junto com o mundo sem fim. Indefinido pela mutação pontuava a sensação da infinitude.

O cão já era quase humano. Provido do verbo compreendeu melhor. Aproximou-se ainda mais do dono. Porém em silêncio prosseguiam a caminhada. Chuva tórrida de sensações novas. A vida recomeçava do caos.

Atracaram numa ilha tropical e pisaram em terra. $\mathrm{O}$ sol ardente se punha sobre eles.Sob a tênue sombra dos coqueirais descasaram da longa viagem...

Veio então uma tempestade de verão ensopando seus corpos como que batizando-os na nova terra. Trovões estrondosos rugiam, ecoando os rastros dos raios que percorriam violentamente o espaço sem fim. Desolados, olhavam o gigantesco e poderoso mar juntando-se ao céu. A fértil e exuberante paisagem agreste adornava a terra enchendo os olhos de beleza. $O$ mar revolto vociferava levantando compridas ondas que se quebravam na praia. A branca espuma era sugada pela areia acolhendo-a em suas entranhas.

Depois da tempestade a calmaria. Sábia natureza. Ouvia-se apenas os cantos dos pássaros e o leve farfalhar dos coqueiros. Puseram-se a caminhar os três adentrando a terra. O ouvido afiado do cão percebeu vozes ao longe e avisou ao Homem. Cautelosos prosseguiram...

Avistaram uma casa e um grupo de pessoas conversando no jardim. Atento, o Homem observava o movimento. Percebeu que havia ali uma bela mulher entre eles. Passaram-se dias e seu olhar atraído não conseguia desviar-se da jovem. Viajou no tempo de seus pensamentos e lembrou-se da princesa por quem havia um dia se apaixonado num remoto passado. Seus suaves movimentos e sua voz grave revelavam sua força. O Homem comovia-se com os detalhes. Os gestos da moça em movimento parecia-lhe uma dança de cometas se explodindo e percorrendo o cosmos.

Certa noite fizeram uma festa no jardim iluminado por tochas de fogo. O Homem lembrou-se da aldeia, das histórias e do rigoroso inverno... Porém uma brisa morna e suave espantou-lhe a longínqua lembrança. Ao som das mais lindas canções os convivas dançavam. O Homem foi tomado de encantamento ao ver os sensuais movimentos da jovem acompanhar a música. Perdidamente apaixonado e como que enfeitiçado, levantou-se num impulso para se aproximar da amada. Destemido tentou penetrar no jardim. Nesse momento percebeu a impossibilidade. Não havia jardim, não havia a moça, não havia ninguém. Mas a música continuava a 
dimensionar aquele mundo. Assustado recuou. Não conseguia compreender o que se passava. Tentou novamente. Quis tocar as imagens que via e aí percebeu a imaterialidade. Perplexo, afastou-se e em sua mente confusa fez um esforço para raciocinar e entender o ocorrido.

O gato subiu-Ihe ao colo e o cão pousou a cabeça em suas pernas cumpliciando o espanto. Ao fim do baile letras garrafais giravam no jardim. O texto dizia que dedicava aquelas cenas à posteridade e glorificava a eternidade da vida repetida infinitas vezes naquele cenário. Daí a pouco tudo recomeçou e o Homem percebeu que já havia presenciado aquelas cenas. Truque da modernidade driblava a brevidade da vida. Exausto de espanto o homem adormeceu e em sonho continuou sua história... Assim se foi para sempre e sempre... 